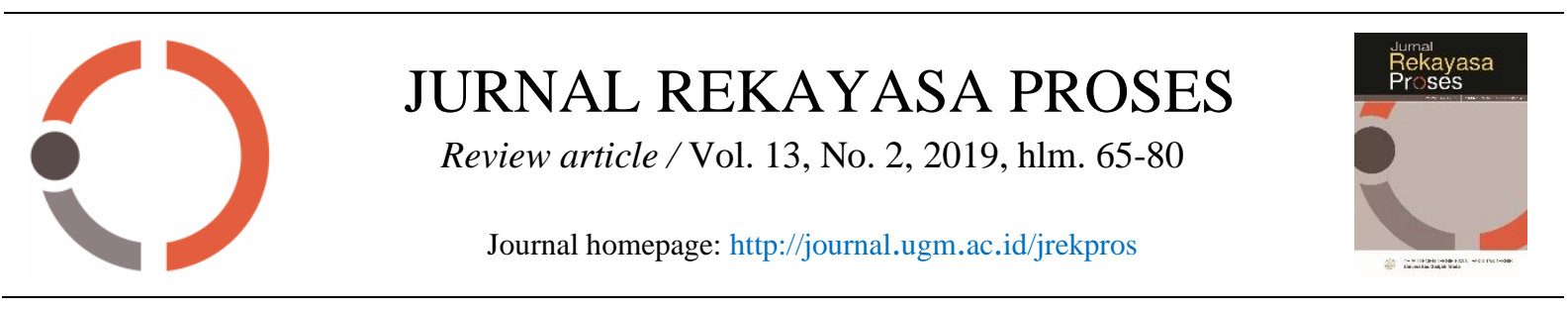

\title{
Pemanfaatan Ekstrak Protein dari Kacang-kacangan sebagai Koagulan Alami: Review
}

\author{
Hans Kristianto*, Susiana Prasetyo, Asaf Kleopas Sugih \\ Jurusan Teknik Kimia, Fakultas Teknologi Industri, Universitas Katolik Parahyangan, Jl. Ciumbuleuit \\ No.94, Hegarmanah, Bandung 40141 \\ * Corresponding author: hans.kristianto@unpar.ac.id
}

(Submisi: 27 Mei 2019; Revisi: 9 September 2019; Penerimaan: 17 Oktober 2019)

\section{A B S T RACT}

Coagulation and flocculation are commonly used in water and wastewater treatment. Inorganic coagulant such as alum $\left(\mathrm{Al}_{2}\left(\mathrm{SO}_{4}\right)_{3}\right)$, ferrous sulphate $\left(\mathrm{FeSO}_{4}\right)$, and polyaluminium chloride (PAC) are commonly used. These coagulants are known for its effectiveness and simple operation procedure. However, there are some drawbacks such as reduction in $\mathrm{pH}$, potential negative health effect when the treated water is consumed, and large sludge volume. To overcome these problems, utilization of natural coagulants has been proposed. Based on its active coagulating agent, natural coagulant could be divided as polyphenolic, polysaccharides, and protein. Protein from beans and seeds is commonly used as the source of active coagulating agent, due to its effectiveness, availability, and relatively simple pretreatment is needed. Usually the protein is extracted by using 0.5-1 M NaCl solution as globulin is the major protein fraction in beans. The extracted protein could act as cationic polymer to neutralize negatively charged colloids through adsorption-charge neutralization mechanism. Extracted protein could work effectively to treat turbid and waste water with lower cost compared to alum. However, most of existing studies are still focused on small - pilot scale utilization thus further explorations are still needed.

Keywords: coagulation; extraction; natural coagulant; protein

\section{A B S T R A K}

Koagulasi dan flokulasi merupakan proses yang umum digunakan dalam pengolahan air dan limbah cair. Pada umumnya digunakan koagulan seperti alum $\left(\mathrm{Al}_{2}\left(\mathrm{SO}_{4}\right)_{3}\right)$, ferro sulfat $\left(\mathrm{FeSO}_{4}\right)$, dan polialuminium klorida (PAC). Selain efektif, koagulasi merupakan proses yang relatif sederhana dan mudah diterapkan. Akan tetapi koagulasi dengan koagulan anorganik memiliki beberapa kekurangan seperti menurunnya $\mathrm{pH}$ menjadi asam saat digunakan, potensi gangguan kesehatan jika air hasil pengolahan terkonsumsi, serta volume sludge yang dihasilkan relatif tinggi. Penggunaan koagulan alami menjadi alternatif dalam pengolahan air untuk mengatasi berbagai kekurangan tersebut. Berdasarkan bahan aktif koagulannya, koagulan alami dapat dibagi menjadi polifenol, polisakarida, dan protein. Protein dari kacang-kacangan merupakan salah satu sumber koagulan alami yang umum digunakan, karena selain efektif, kacang-kacangan mudah didapat, serta membutuhkan perlakuan yang relatif sederhana, meliputi pengeringan, pengecilan ukuran, ekstraksi, serta purifikasi. Proses ekstraksi kacang-kacangan pada umumnya menggunakan larutan garam $\mathrm{NaCl}$ dengan konsentrasi $0,5-1 \mathrm{M}$, dikarenakan fraksi protein dominan pada protein kacang-kacangan pada umumnya berupa globulin. Protein yang terekstrak berfungsi sebagai polimer kationik yang cocok digunakan untuk mengolah koloid yang bermuatan negatif melalui mekanisme adsorpsi-netralisasi muatan. Pemanfaatan ekstrak protein dapat bekerja efektif untuk mengolah kekeruhan dan air limbah, dengan biaya yang lebih 
rendah dibandingkan alum. Akan tetapi pemanfaatannya masih pada skala laboratorium-pilot, sehingga diperlukan pengembangan lebih lanjut untuk isolasi ekstrak serta aplikasinya pada skala industri.

Kata kunci: ekstraksi; koagulan alami; koagulasi; protein

\section{Pendahuluan}

Koagulasi dan flokulasi merupakan proses yang umum digunakan dalam pengolahan air dan limbah cair. Koagulasi dan flokulasi pada umumnya digunakan untuk menurunkan kekeruhan, mikroorganisme, warna, senyawa organik, dan sebagainya. Koagulan dan flokulan yang umum digunakan berupa garam anorganik seperti aluminium sulfat $\left(\mathrm{Al}_{2}\left(\mathrm{SO}_{4}\right)_{3}\right)$, ferro sulfat $\left(\mathrm{FeSO}_{4}\right)$, dan ferri sulfat $\left(\mathrm{Fe}_{2}\left(\mathrm{SO}_{4}\right)_{3}\right)$, serta koagulan yang terhidrolisis (pre-hydrolyzed coagulants) seperti poliferro sulfat (polyferrous sulphate - PFS), poliferri klorida (polyferric chloride - PFC), dan polialuminium klorida (polyaluminium chloride - PAC) (Verma dkk., 2012). Koagulan yang disebutkan sebelumnya memiliki performa yang unggul dalam pengolahan air, akan tetapi memiliki beberapa kekurangan seperti efisiensi yang rendah pada suhu dingin di negara empat musim, $\mathrm{pH}$ air yang turun setelah pengolahan, jumlah sludge volume yang besar, harga yang cukup tinggi, serta potensi menyebabkan masalah kesehatan (Alzheimer, demensia) (Srinivasan dkk., 1999; Theodoro dkk., 2013; Yin, 2010). Pemanfaatan koagulan alami menawarkan solusi dari berbagai kekurangan di atas.

Koagulan alami memiliki keunggulan seperti mudah terurai oleh mikroorganisme (biodegradable), tersedia dalam jumlah banyak, harga relatif murah, volume sludge lebih sedikit, floc yang terbentuk lebih kuat dan stabil, serta non-toksik (Verma dkk., 2012). Koagulan alami dapat berasal dari tumbuh-tumbuhan, hewan, maupun mikroorganisme. Koagulan alami yang cukup dikenal dari sumber hewani seperti kitosan (Asif dkk., 2016) yang berasal dari cangkang kepiting dan udang, atau protein dari sisik ikan (Musa dkk., 2015). Meskipun demikian koagulan alami dari tumbuh-tumbuhan relatif lebih mudah diperoleh sehingga berpotensi untuk dikembangkan dan digunakan (Choy dkk., 2015). Koagulan alami yang berasal dari tumbuhtumbuhan memiliki bahan aktif berupa polisakarida, polifenol, atau protein.

Polisakarida merupakan rantai panjang dari monomer monosakarida yang terhubung oleh ikatan glikosidik. Dalam tanaman, poliksakarida pada umumnya dijumpai sebagai pembentuk struktur dinding sel (selulosa, kitin) dan cadangan makanan (pati) (Guo dkk., 2017). Polisakarida dapat menjadi bahan aktif koagulan namun tidak dapat langsung digunakan, sehingga diperlukan modifikasi. Pada penelitian yang dilakukan oleh Teh dkk. (2014) dan Choy dkk. (2016), pemanfaatan pati dari beras, gandum, jagung, dan kentang secara langsung dapat meningkatkan kekeruhan di dalam air karena partikel pati yang tersuspensi. Berbagai pati tersebut dapat digunakan sebagai koagulan alami setelah melalui proses gelatinisasi $\left(121^{\circ} \mathrm{C}, 17 \mathrm{psi}\right.$ selama 20 min) (Choy dkk., 2016; Teh dkk., 2014). Upaya lain yang dapat digunakan untuk meningkatkan performa pati sebagai koagulan alami adalah dengan mencangkokkan kopolimer ke dalam struktur pati (grafting) sehingga memberikan muatan pada struktur pati (Oladoja dkk., 2017). Beberapa kopolimer yang dicangkokkan antara lain: polyacrylamide (Rath dan Singh, 1997), polyacrylonitrile (Mishra dkk., 2004), dan polymethyl methacrylate (Kumar dkk., 2013). Meskipun produk pati termodifikasi tersebut dapat bekerja efektif sebagai koagulan alami, namun terdapat beberapa kekurangan. Beberapa kekurangan dari pati termodifikasi yaitu proses modifikasi yang rumit, biaya produksi yang mahal, serta risiko lepasnya monomer atau reaktan yang tidak bereaksi dan bersifat toksik ke lingkungan (Lee dkk., 2014).

Polifenol yang berasal dari tumbuhan juga dapat berfungsi sebagai bahan aktif koagulan. Beberapa jenis tumbuhan yang dieksplorasi sebagai sumber polifenol untuk koagulan alami 
antara lain: biji anggur (Jeon dkk., 2009), biji pohon ek (Ozacar dan Sengil, 2002), dan kulit pohon akasia (Singh dkk., 2016). Polifenol yang umumnya digunakan sebagai koagulan alami adalah tanin, dikarenakan sifatnya yang larut dalam air. Berdasarkan penelitian yang dilakukan oleh Ozacar dan Sengil (2002), penggunaan tanin yang tidak dimodifikasi lebih cocok sebagai bahan pembantu koagulan, yaitu digunakan untuk menurunkan dosis alum yang digunakan dalam proses koagulasi. Pada umumnya tanin dari ekstrak tanaman dimodifikasi lebih lanjut menghasilkan tanin-kationik melalui reaksi Mannich (Beltrán-Heredia dkk., 2010), yaitu tanin dengan senyawa amina (ammonium klorida, dietanolamina) dan formaldehida.

Jika dibandingkan dengan berbagai bahan aktif koagulan yang dijelaskan sebelumnya, bahan aktif koagulan berupa protein memerlukan perlakuan yang lebih sederhana. Protein yang berasal dari tumbuhan dapat diperoleh dari sayursayuran, buah-buahan, atau kacang-kacangan. Di antara tumbuhan tersebut, kandungan protein tertinggi terdapat pada kacang-kacangan (Nehete dkk., 2013). Pengolahan kacang-kacangan sebagai koagulan dapat dibagi menjadi tiga tahap, yaitu primer, sekunder, dan tersier (disajikan pada Gambar 1). Pengolahan primer mencakup perlakuan fisik, meliputi pencucian, pengupasan, pengeringan, dan pengecilan ukuran bahan alam. Pengolahan sekunder berfokus pada proses ekstraksi bahan aktif koagulan, sementara pengolahan tersier merupakan tahap pemurnian untuk memperoleh isolat bahan aktif (Yin, 2010). Pemanfaatan kacang-kacangan secara langsung sebagai koagulan alami dapat dilakukan. Namun, terdapat kemungkinan komponen lain selain komponen koagulan aktif dapat terekstrak ke dalam air yang diolah, sehingga dapat meningkatkan nilai oksigen terlarut atau oxygen demand (OD). Proses sekunder bertujuan untuk meningkatkan efektivitas proses koagulasi, yaitu mengambil bahan aktif koagulan sehingga peningkatan nilai OD menjadi lebih minim. Komponen organik dari ekstrak yang tidak diinginkan dapat dipisahkan pada proses tersier, yang memungkinkan bahan aktif koagulan diperoleh sebagai isolat murni. Akan tetapi, proses tersier cukup sulit dilakukan dan mahal, sehingga lebih cocok dijajaki dalam rangka komersialisasi koagulan alami (Yin, 2010). Pada tinjauan (review) ini, disajikan potensi pemanfaatan kacang-kacangan sebagai koagulan alami, meliputi kacang-kacangan yang umum dijumpai di Indonesia, proses ekstraksi, serta pemanfaatannya. Lebih lanjut peluang dan tantangan pengembangan penelitian koagulan alami dari protein kacang-kacangan dipaparkan dalam tinjauan ini.

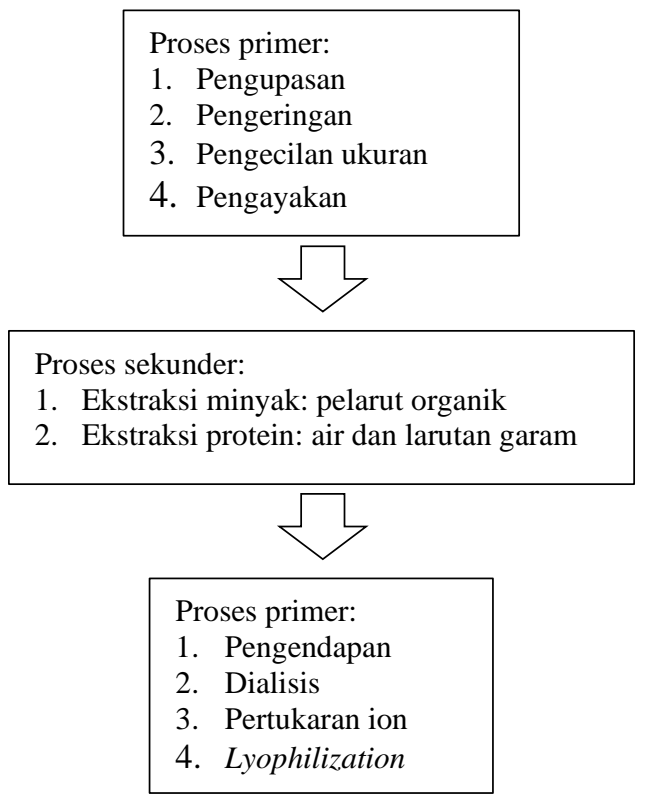

Gambar 1. Skema perlakuan dalam pemanfaatan koagulan alami (diadaptasi dari Yin, 2010)

\section{Potensi Kacang-kacangan sebagai Koagulan Alami}

Secara umum protein dalam kacang-kacangan dapat digolongkan menjadi protein metabolik (enzim dan non enzim) dan cadangan makanan (disebut juga protein globular) (Sathe, 2002). Berdasarkan kelarutannya, protein dapat digolongkan menjadi albumin, yaitu protein yang larut dalam air, globulin, protein yang larut dalam larutan garam, glutein, larut dalam asam atau basa encer, dan prolamin, larut dalam campuran air/alkohol (Shewry dkk., 1995). Kandungan protein dan komposisinya disajikan pada Tabel 1. Pada umumnya kacang-kacangan memiliki kandungan globulin yang paling tinggi (Shewry dkk., 1995), yaitu berkisar antara 50-70\% dari total fraksi protein. Globulin dapat digolongkan 
menjadi globulin tipe visilin (7S) dan tipe legumin (11S) berdasarkan koefisien sedimentasinya. Koefisien sedimentasi protein menggambarkan ukuran dan berat molekul dari struktur protein. Struktur visilin terdiri atas protein dengan berat molekul antara 150-190 $\mathrm{kDa}$, yang tersusun oleh tiga sub-unit protein (43$53 \mathrm{kDa}$ ) (Shewry dkk., 1995). Struktur legumin (300-400 kDa) terdiri atas enam sub-unit protein yang dapat bersifat asam $(40 \mathrm{kDa})$ atau basa
(20kDa) dan dihubungkan oleh ikatan sulfida (Müntz, 1998). Pada struktur sel biji-bijian, visilin dan legumin tersimpan pada vakoula (Mainieri dkk., 2014) yang dikenal sebagai badan protein. Oleh karena itu, pada proses ekstraksi protein dari kacang-kacangan, dibutuhkan upaya untuk merusak dinding sel, agar pelarut dapat berdifusi masuk untuk mengambil protein di dalam sel.

Tabel 1. Kandungan protein dan komposisinya untuk beberapa jenis kacang-kacangan

\begin{tabular}{|c|c|c|c|c|c|c|c|}
\hline \multirow[t]{2}{*}{ Kacang-kacangan } & \multirow{2}{*}{$\begin{array}{l}\text { \%-b protein } \\
\text { (basis kering) }\end{array}$} & \multirow[b]{2}{*}{ albumin } & \multicolumn{3}{|c|}{$\%$ Fraksi protein } & \multirow[b]{2}{*}{$\begin{array}{c}\text { residu } \\
\text { tak larut }\end{array}$} & \multirow[t]{2}{*}{ Pustaka } \\
\hline & & & globulin & glutein & prolamin & & \\
\hline $\begin{array}{l}\text { Kelor (Moringa } \\
\text { oleifera) }\end{array}$ & $44,8 \pm 3,04$ & 44,00 & 53,00 & 0,39 & 0,56 & 2,5 & (Baptista dkk., 2017) \\
\hline $\begin{array}{l}\text { Petai cina (Leucaena } \\
\text { leucocephala) }\end{array}$ & $57,8-64,16$ & 28,4 & 43,5 & 25 & N/A & 3,11 & $\begin{array}{l}\text { (Sethi dan Kulkarni, 1993; } \\
\text { Sethi dan Kulkarni, 1994) }\end{array}$ \\
\hline $\begin{array}{l}\text { Kacang tanah (Arachis } \\
\text { hypogaea) }\end{array}$ & $6,8-12,0$ & $2-3$ & $94-95$ & $0,5-1,5$ & $1-2$ & N/A & (Sebei dkk., 2013) \\
\hline $\begin{array}{l}\text { Kacang merah } \\
\text { (Phaseolus angularis) }\end{array}$ & $17,96-22,07$ & $12-30$ & $54-79$ & $20-30$ & $2-4$ & N/A & $\begin{array}{l}\text { (Shimelis dan Rakshit, 2005; } \\
\text { Natarajan dkk., 2013) }\end{array}$ \\
\hline $\begin{array}{l}\text { Kacang kedelai } \\
\text { (Glycine } \max )\end{array}$ & $35,35-39,80$ & 22,90 & 46,50 & 30,40 & 0,2 & N/A & (Ciabotti dkk., 2016) \\
\hline $\begin{array}{l}\text { Kacang babi (Vicia } \\
\text { faba) }\end{array}$ & $31,8-39,7$ & 1,41 & 73,6 & 2,68 & 13,2 & N/A & (Alghamdi, 2009) \\
\hline $\begin{array}{l}\text { Kecipir (Psophocarpus } \\
\text { tetragonolobus) }\end{array}$ & 38,31 & 24,46 & 31,94 & 12,59 & 4,05 & 24,96 & (Makeri dkk., 2017) \\
\hline
\end{tabular}

Keterangan: N/A = data tidak tersedia

\section{Proses Ekstraksi Protein}

Proses primer (Gambar 1) yang terdiri atas pengupasan, pengeringan, pengecilan ukuran, dan pengayakan, merupakan perlakuan awal yang dibutuhkan untuk meningkatkan efektivitas dan efisiensi dari ekstraksi protein. Pengeringan bertujuan untuk menurunkan kandungan air di dalam kacang-kacangan sehingga menghambat aktivitas mikroorganisme yang dapat mendegradasi protein (Siddique dan Wright, 2003). Selain itu pengeringan juga berfungsi untuk mempermudah proses pengecilan ukuran. Perlakuan awal untuk merusak dinding sel dalam rangka melakukan ekstraksi dapat dilakukan dengan berbagai metode, akan tetapi perlakukan secara mekanis, seperti penghalusan dan ekstruksi merupakan proses yang paling mudah dan umum digunakan (Campbell dkk., 2011). Perlakuan secara mekanis diketahui secara efektif dapat merusak hampir seluruh total dinding sel, tetapi tidak sampai merusak ekstrak yang ingin diambil.

Perlakuan awal dengan mengekstraksi kandungan minyak dibutuhkan jika kacangkacangan memiliki kandungan minyak yang tinggi. Kandungan minyak yang tinggi dapat mengurangi kontak pelarut sehingga menurunkan efisiensi ekstraksi secara keseluruhan (Choi dkk., 2017). Selain itu minyak yang diekstrak dapat dimanfaatkan lebih lanjut, atau memiliki nilai jual. Muyibi dkk. (2002) membandingkan biji kelor yang diberi perlakuan awal ekstraksi minyak untuk menghilangkan kekeruhan air. Diperoleh hasil biji kelor yang sudah diekstrak minyaknya memberikan persentase penurunan (\% removal) yang lebih besar $1 \%$ pada air yang sangat keruh (320-450 NTU), dan 6\% pada air dengan kekeruhan rendah (50-60 NTU) dengan dosis serbuk kelor yang lebih sedikit $50 \mathrm{mg} / \mathrm{L}$ (Muyibi dkk., 2002). Perbedaan tersebut diduga 
karena minyak pada serbuk biji kelor menyebabkan munculnya lapisan film di permukaan serbuk. Hal ini dapat membatasi interaksi di permukaan sehingga menurunkan pembentukan flok.

Garcia-Fayos, dkk (2016) melakukan perbandingan metode ekstraksi minyak (dispersi dengan pengadukan dan soxhletasi) dan pelarut (heksana, etanol, dan aseton) sebelum dilakukan ekstraksi protein dari biji kelor dengan menggunakan air. Metode soxhletasi memberikan perolehan minyak lebih besar dua kali lipat (32$34 \% \mathrm{~b} / \mathrm{b}$ ) dibandingkan kontak pelarut umpan menggunakan dispersi dengan pengadukan. Lebih lanjut dikemukakan bahwa proses ekstraksi minyak tidak mengubah jenis protein yang diperoleh saat ekstraksi protein, yaitu protein dengan berat molekul di bawah 6,5 kDa. Akan tetapi protein dari biji kelor yang diekstrak dengan etanol memberikan performa koagulasi (\% removal) yang lebih unggul $(91,6 \%)$ dibandingkan pelarut heksana $(86,4 \%)$ dan aseton $(85,8 \%)$ dengan dosis koagulan yang lebih sedikit (Garcia-Fayos dkk., 2016). Hal ini diduga akibat interaksi protein dengan pelarut organik yang dapat memodifikasi struktur dan sifat protein, sehingga meningkatkan performa-nya sebagai koagulan.

Diketahui beberapa variabel proses yang dapat memengaruhi proses ekstraksi protein dari kacang-kacangan, yaitu: jenis garam, konsentrasi garam, dan $\mathrm{pH}$ ekstraksi. Pengaruh jenis garam (kation dan anion) terhadap proses ekstraksi dapat dinyatakan dalam deret Hofmeister yang disajikan pada Gambar 2.

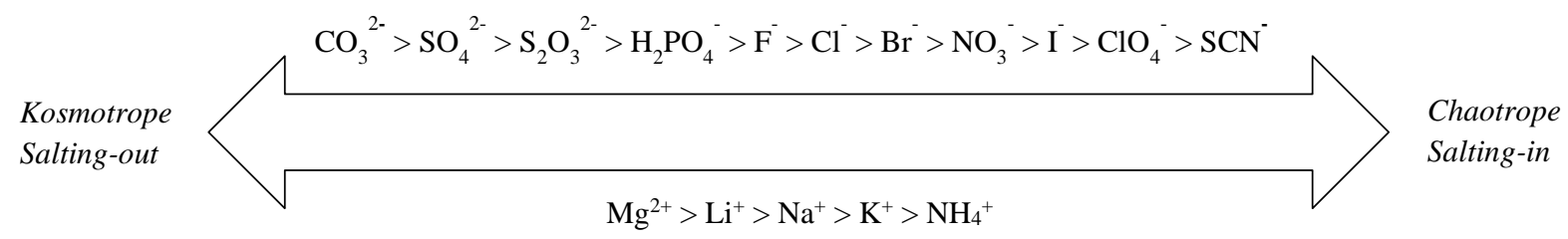

Gambar 2. Deret Hofmeister untuk anion dan kation (diadaptasi dari Zhang, 2012)

Berdasarkan interaksi protein dan garam di dalam air, dikenal dua jenis fenomena yaitu salting-in dan salting-out. Hal ini dimungkinkan karena sifat garam yang digolongkan menjadi garam yang terhidrasi kuat (kosmotrope) dan terhidrasi lemah (chaotrope). Protein yang tersusun atas berbagai asam amino, memiliki gugus-gugus polar atau pun non polar. Monomer asam amino polar (biasanya bermuatan negatif) cenderung terhidrasi kuat di dalam air (kosmotrope), sedangkan asam amino non polar terhidrasi lemah (chaotrope). Ion-ion terlarut dapat berinteraksi dengan protein, sehingga meningkatkan kelarutan protein di dalam air (salting in), dibandingkan tanpa kehadiran ionion. Sementara itu, garam kosmotrope dapat terhidrasi kuat di dalam air, sehingga menyebabkan air menjadi pelarut yang lebih buruk (Collins, 2004). Hal ini menyebabkan menurunnya kelarutan protein (salting out). Secara sederhana interaksi yang terjadi disajikan pada Gambar 3.

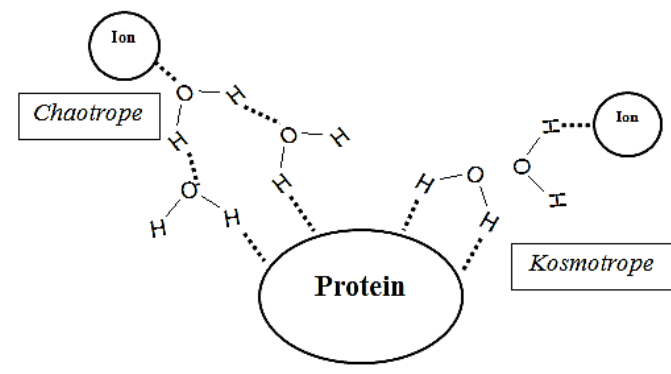

Gambar 3. Ilustrasi interaksi protein, air, dan ion garam dalam proses pelarutan protein (diadaptasi dari Collins, 2004)

Konsentrasi garam yang digunakan juga merupakan parameter penting yang memengaruhi proses ekstraksi protein. Peningkatan konsentrasi $\mathrm{NaCl}$ dari 0-1 M pada ekstraksi protein dari kacang walnut, semakin tinggi konsentrasi garam yang digunakan, maka protein yang terekstrak akan semakin banyak karena efek salting in $\mathrm{Hu}$ dkk., 2017). Pada konsentrasi garam yang terlalu tinggi, garam akan membentuk ikatan yang lebih stabil dengan air (terhidrasi kuat), sehingga menyebabkan peningkatan sifat hidrofobik dari 
protein (Hyde dkk., 2017) dan meningkatkan afinitas antar molekul protein yang menyebabkan terjadinya agregasi (Zhang, 2012). Hal ini menyebabkan kelarutan protein menjadi menurun (salting out).

Selain jenis dan konsentrasi garam, $\mathrm{pH}$ larutan juga memengaruhi proses ekstraksi protein. Protein merupakan molekul amfoterik yang dapat bermuatan positif atau pun negatif, bergantung pada $\mathrm{pH}$ larutan. Pada $\mathrm{pH}$ di bawah titik isoelektriknya (pI) asam amino akan bermuatan positif, jika di atas pI, maka akan bermuatan negatif. Muatan pada protein tersebut berkontribusi terhadap peningkatan kelarutan protein. Pada umumnya, profil pelarutan protein terhadap pH menyerupai huruf "U". Pada profil kelarutan protein terdapat area kelarutan terendah yaitu pada sekitar pI dan 2 area kelarutan tinggi pada $\mathrm{pH}$ asam di bawah pI, serta basa di atas pI (Shehata dan Thannoun, 1981; Swamylingappa dan Srinivas, 1994).

Dalam pemanfaatan kacang-kacangan sebagai koagulan alami, telah diteliti variasi garam serta konsentrasi ekstraksi protein. Namun, pH ekstraksi secara umum tidak pernah divariasikan (mengikuti pH air). Okuda, dkk. (1999) melakukan variasi jenis garam $\left(\mathrm{NaCl}, \mathrm{KNO}_{3}\right.$, $\mathrm{KCl}$, dan $\mathrm{NaNO}_{3}$ ) untuk mengekstrak protein dari Moringa oleifera. Diperoleh hasil dengan variasi jenis garam memberikan performa yang sama (95\%) pada penghilangan kekeruhan dari limbah sintetik kaolin (50 NTU). Lebih lanjut dilakukan variasi konsentrasi garam, yaitu diperoleh peningkatan aktivitas koagulan sampai ekstrak dengan konsentrasi $1 \mathrm{M}$. Pada konsentrasi $3 \mathrm{M}$, performa menurun, diduga disebabkan oleh penurunan konsentrasi protein yang terekstrak sebagai akibat dari fenomena salting out (Okuda dkk., 1999). Hasil serupa juga diperoleh pada penelitian Birima dkk. (2013) untuk ekstraksi protein kacang tanah dan penelitian Dalvand dkk. (2016) untuk ekstraksi Moringa stenopelata dengan berbagai jenis garam. Oleh karena itu, proses ekstraksi protein dari kacang-kacangan sebagai koagulan alami pada umumnya menggunakan larutan garam $\mathrm{NaCl}$. Hal ini didasarkan pada hasil yang diperoleh dari penelitian sebelumnya, selain juga ketersediaannya yang berlimpah dan harga yang relatif murah. Akan tetapi, pemanfaatan larutan garam $\mathrm{NaCl}$ memiliki kelemahan, yaitu masih terdapat komponen organik lain yang dapat ikut terekstrak, sehingga diperlukan pengolahan air lebih lanjut. Ramavandi (2014) mencetuskan pemanfaatan garam $\mathrm{FeCl}_{3}$ dalam ekstraksi protein dari Plantago ovata dengan peningkatan nilai dissolved organic carbon hanya sebesar 20\%, jika dibandingkan ekstrak dengan garam lain yang dapat mencapai 50\% . Hal ini diduga karena ion $\mathrm{Fe}^{3+}$ juga dapat berfungsi sebagai koagulan sehingga meningkatkan efisiensi keseluruhan proses koagulasi. Akan tetapi penggunaan $\mathrm{FeCl}_{3}$ dalam proses ekstraksi protein belum dilakukan pada sumber protein lain, sehingga diperlukan penelitian lanjutan untuk mengonfirmasi kecenderungan yang sama pada berbagai kacangkacangan.

Proses ekstraksi protein dari kacang-kacangan pada umumnya menggunakan proses kontak secara dispersi. Terdapat beberapa peneliti yang melakukan eksplorasi terhadap metode ekstraksi. Abidin dkk. (2013) membandingkan proses ekstraksi bahan aktif koagulan dari biji Jatropha curcas dengan metode dispersi dan dispersi dibantu gelombang ultrasonik. Ekstraksi dengan bantuan gelombang ultrasonik (42 kHz) memberikan performa koagulan yang sama tetapi waktu ekstraksi yang dibutuhkan lebih singkat (1 menit) dibandingkan dispersi menggunakan alat penghalus makanan saja (2 menit) (Abidin dkk., 2013). Gelombang ultrasonik menyebabkan fenomena kavitasi yang memunculkan gaya geser yang tinggi dan menyebabkan peningkatan turbulensi dan peluruhan partikel sehingga secara umum meningkatkan perpindahan massa ekstrak dan pelarut (Vilkhu dkk., 2008). Ekstraksi dengan menggunakan alat penghalus makanan komersil (Abidin dkk., 2017; Muthuraman dan Sasikala, 2014; Muyibi dan Alfugara, 2003) membutuhkan waktu ekstraksi yang jauh lebih cepat jika dibandingkan dispersi dengan pengadukan biasa. Hal ini diduga karena turbulensi yang tinggi sehingga membantu mempersingkat waktu yang dibutuhkan dalam proses ekstraksi. 
Berdasarkan uraian di atas, dapat disimpulkan bahwa kacang-kacangan membutuhkan perlakuan awal berupa pengeringan dan pengecilan ukuran sebelum proses ekstraksi. Secara umum penggunaan larutan garam $\mathrm{NaCl}$ dengan konsentrasi 0,5-1M merupakan pelarut yang paling umum digunakan dalam ekstraksi protein dari kacang-kacangan. Hal ini diakibatkan fraksi globulin yang larut di dalam larutan garam pada umumnya merupakan fraksi yang paling banyak pada protein kacang-kacangan, seperti yang telah dipaparkan pada Tabel 1. Sementara itu, proses ekstraksi dapat dilakukan dengan dibantu pengadukan (dispersi) dalam waktu yang relatif singkat. Sementara berbagai upaya mempercepat tercapainya kesetimbangan ekstraksi menggunakan bantuan gelombang ultrasonik atau pengadukan dengan turbulensi tinggi (misal alat penghalus makanan komersil) dapat menjadi alternatif, akan tetapi tidak menggeser kesetimbangan ekstraksi.

\section{Ekstrak Protein sebagai Koagulan Alami}

Secara umum dikenal empat mekanisme destabilisasi koloid yaitu kompressi lapisan ganda, netralisasi muatan, intraparticle bridging, dan sweep flocculation. Kompresi lapisan ganda (double layer compression) pada umumnya terjadi karena kehadiran ion-ion dalam jumlah cukup besar yang menyebabkan berkurangnya diameter lapisan ganda. Hal ini mengakibatkan gaya tolak menolak elektrostatik antar partikel koloid menjadi lebih kecil dan memungkinkan pembentukan flok (Gregory, 2006). Netralisasi muatan (charge neutralization) terjadi saat muatan permukaan koloid dinetralkan oleh penambahan koagulan yang menyebabkan menurunnya gaya tolak menolak elektrostatik pada koloid. Interparticle bridging terjadi saat rantai polimer teradsorpsi di permukaan koloid, sehingga menjembatani pembentukan agregat antar koloid. Mekanisme terakhir adalah sweep flocculation yang umum terjadi pada penggunaan koagulan anorganik berlebih yang membentuk hidroksida yang akan mengendap. Koloid akan terperangkap di dalam endapan hidroksida dan mengendap secara bersamaan.

Di antara berbagai mekanisme yang sudah dijelaskan sebelumnya, pada umumnya protein mengikuti mekanisme netralisasi muatan. Hal ini dikarenakan protein merupakan senyawa amfoterik yaitu dapat bermuatan positif atau negatif bergantung pada titik isoelektriknya. Gugus amino dalam struktur protein berperan sebagai pusat kationik dalam mekanisme netralisasi muatan yang dapat menetralkan koloid yang pada umumnya bermuatan negatif. Protein diketahui sebagai senyawa polielektrolit dapat menempel pada permukaan koloid melalui mekanisme electrostatic patch (Bolto dan Gregory, 2007). Mekanisme netralisasi muatan dilaporkan dalam penggunaan ekstrak protein dari Moringa oleifera (Ndabigengesere dkk., 1995), Jatropha curcas (Abidin dkk., 2011), Moringa stenopelata (Dalvand dkk., 2016), Leucaena leucocephala (Kristianto dkk., 2018).

Parameter utama yang berpengaruh dalam proses koagulasi yaitu $\mathrm{pH}$ larutan dan dosis koagulan. $\mathrm{pH}$ larutan memiliki peranan yang sangat penting dalam proses koagulasi, terutama ketika protein dimanfaatkan sebagai bahan aktif koagulan. Hal ini berkaitan dengan sifat protein sebagai molekul amfoterik yaitu dapat bermuatan positif atau negatif, bergantung pada $\mathrm{pH}$ larutan. Oleh karena itu, pada umumnya proses koagulasi dilakukan di bawah pI nya, sehingga protein akan bermuatan positif dan dapat menetralisasi koloid yang umumnya bermuatan negatif. Nilai pI dari protein sangat bergantung pada asam amino penyusunnya (Audain dkk., 2016). Beberapa pI dari kacang-kacangan disajikan pada Tabel 2.

Secara umum diketahui tiga jenis skenario penambahan dosis koagulan, yaitu pada saat dosis di bawah titik optimum, optimum, dan berlebih (Choy dkk., 2015). Skema proses koagulasi pada berbagai dosis disajikan pada Gambar 4. Pada penambahan dosis yang terlalu rendah, proses koagulasi tidak dapat berjalan dengan baik, karena tidak ada cukup koagulan untuk menetralkan permukaan koloid, sehingga zeta potensial larutan di bawah nol. Hal ini berdampak pada rendahnya performa (penurunan konsentrasi koloid) di dalam larutan. Pada saat 
penambahan koagulan dengan dosis optimum, muatan koloid ternetralisasi sehingga zeta potensial larutan mencapai nol. Performa koagulan terbaik diperoleh pada titik ini. Penambahan koagulan berlebih dapat menurunkan performa dan efektivitas proses koagulasi. Hal ini diakibatkan terlalu banyak koagulan yang menempel di permukaan koloid memberikan muatan dan menyebabkan gaya tolak-menolak elektrostatik muncul kembali. Fenomena ini dikenal dengan restabilisasi koloid.

Tabel 2. Nilai pI dari beberapa jenis kacang-kacangan

\begin{tabular}{lcl}
\hline \multicolumn{1}{c}{ Kacang-kacangan } & $\mathrm{pI}$ & \multicolumn{1}{c}{ Pustaka } \\
\hline $\begin{array}{l}\text { Buncis } \\
\text { (Phaseolus vulgaris) }\end{array}$ & $4-5,5$ & (Antov dkk., 2010) \\
$\begin{array}{l}\text { Kelor } \\
\text { (Moringa oleifera) }\end{array}$ & $10-11$ & $\begin{array}{l}\text { (Ndabigengesere dkk., } \\
\text { Kacang babi }\end{array}$ \\
$\begin{array}{l}\text { (Vicia faba) } \\
\text { Kacang kedelai } \\
\text { (Glycine max) }\end{array}$ & $4,0-5,3$ & $\begin{array}{l}\text { (Fernandez-Quintela } \\
\text { dkk., 1997) } \\
\text { Kecipir (Psophocarpus } \\
\text { tetragonolobus) }\end{array}$ \\
$\begin{array}{l}\text { Kacang merah } \\
\text { (Phaseolus angularis) }\end{array}$ & $3,5-5,0$ & (Makeri dkk., 2017) \\
\hline
\end{tabular}

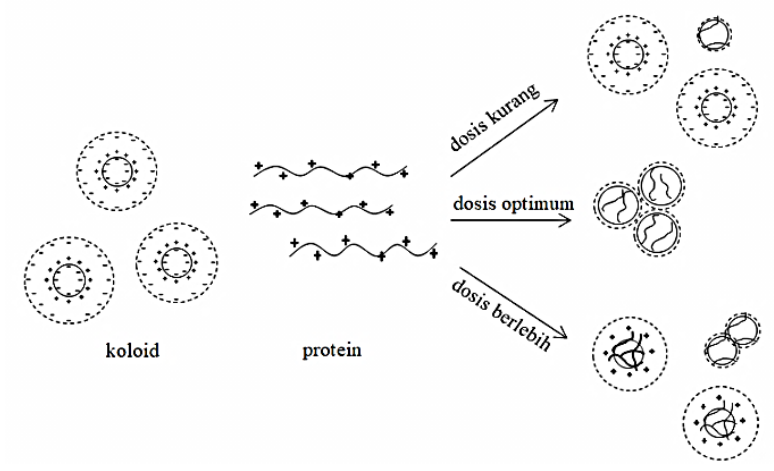

Gambar 4. Pengaruh dosis koagulan terhadap proses koagulasi (diadaptasi dari Bolto dan Gregory (2007); Chen dan Berg (1993); Choy dkk., (2015))

\section{Potensi Pengembangan dan Tantangan ke Depan}

Perkembangan penelitian koagulan alami yang semakin pesat, mendorong eksplorasi berbagai sumber bahan aktif koagulan, serta aplikasinya pada berbagai jenis air dan limbah cair (disajikan pada Tabel 3).

Tabel 3. Kinerja ekstrak protein kacang-kacangan sebagai koagulan alami

\begin{tabular}{|c|c|c|c|c|c|c|}
\hline \multirow[t]{2}{*}{ Koagulan alami } & \multirow[t]{2}{*}{ Kondisi ekstraksi } & \multirow[t]{2}{*}{ Jenis air } & \multicolumn{3}{|c|}{ Kondisi operasi terbaik } & \multirow[t]{2}{*}{ Referensi } \\
\hline & & & Dosis & $\mathrm{pH}$ & \% removal & \\
\hline $\begin{array}{l}\text { Leucaena } \\
\text { leucocephala }\end{array}$ & $\begin{array}{l}\text { Ekstraksi dengan } \\
3 \mathrm{M} \mathrm{NaCl}\end{array}$ & $\begin{array}{l}\text { Limbah sintetik Kongo } \\
\text { merah (50 ppm) }\end{array}$ & $10 \mathrm{~mL} / \mathrm{L}$ & 3 & 99 & (Kristianto dkk., 2019) \\
\hline Phaseolus vulgaris & $\begin{array}{l}\text { Ekstraksi dengan } \\
0,5 \mathrm{M} \mathrm{NaCl}\end{array}$ & $\begin{array}{l}\text { Limbah sintetik Kongo } \\
\text { merah }(50 \mathrm{ppm})\end{array}$ & $30 \mathrm{~mL} / \mathrm{L}$ & 4 & 73 & $\begin{array}{l}\text { (Vijayaraghavan dan } \\
\text { Shanthakumar, 2016) }\end{array}$ \\
\hline Moringa oleifera & $\begin{array}{l}\text { Ekstraksi dengan } \\
\text { air }\end{array}$ & $\begin{array}{l}\text { Limbah sintetik Kongo } \\
\text { merah }(50 \mathrm{ppm})\end{array}$ & $1260 \mathrm{mg} / \mathrm{L}$ & 3 & 99 & (Chethana dkk., 2016) \\
\hline Moringa oleifera & $\begin{array}{l}\text { Ekstraksi dengan } \\
\mathrm{NaCl} 1 \mathrm{M}\end{array}$ & $\begin{array}{l}\text { Limbah sintetik kaolin } \\
\text { (50 NTU) }\end{array}$ & $4 \mathrm{~mL} / \mathrm{L}$ & - & 95 & (Okuda dkk., 1999) \\
\hline Arachis hypogaea & $\begin{array}{l}\text { Ekstraksi dengan } \\
\mathrm{NaCl} 2 \mathrm{M}\end{array}$ & $\begin{array}{l}\text { Palm oil mill effluent } \\
(11.684 \text { NTU, } 22.784 \\
\mathrm{mg} / \mathrm{L}, \mathrm{COD} 63.955 \\
\mathrm{mg} / \mathrm{L})\end{array}$ & $5000 \mathrm{mg} / \mathrm{L}$ & - & $\begin{array}{l}\text { Turbiditas: } \\
\text { 95,5 } \\
\text { TSS: } 94,7 \text {, } \\
\text { COD: } 73,5\end{array}$ & (Birima dkk., 2015) \\
\hline Arachis hypogaea & $\begin{array}{l}\text { Ekstraksi dengan } \\
\mathrm{NaCl} 6 \mathrm{M}\end{array}$ & $\begin{array}{l}\text { Limbah sintetik kaolin } \\
\text { (200 NTU) }\end{array}$ & $20 \mathrm{mg} / \mathrm{L}$ & - & 92 & (Birima dkk., 2013) \\
\hline Vicia faba $L$. & $\begin{array}{l}\text { Ekstraksi dengan } \\
\text { air }\end{array}$ & $\begin{array}{l}\text { Limbah sintetik kaolin } \\
\text { (45 NTU) }\end{array}$ & $0,25 \mathrm{~mL} / \mathrm{L}$ & 7 & 54 & (Kukic dkk., 2015) \\
\hline Glycine $\max$ & $\begin{array}{l}\text { Ekstraksi dengan } \\
\text { air }\end{array}$ & $\begin{array}{l}\text { Air keruh: Turbiditas } \\
\text { (482 NTU, Kesadahan: } \\
88,5 \mathrm{mg} / \mathrm{L} \text { sebagai } \\
\mathrm{CaCO}_{3} \text { ) }\end{array}$ & $1000 \mathrm{mg} / \mathrm{L}$ & 7,6 & 94,37 & (Mbogo, 2008) \\
\hline Arachis hypogea & $\begin{array}{l}\text { Ekstraksi dengan } \\
\text { air }\end{array}$ & & $1000 \mathrm{mg} / \mathrm{L}$ & 7,6 & 84,27 & \\
\hline $\begin{array}{l}\text { Phaseolus } \\
\text { angularis }\end{array}$ & $\begin{array}{l}\text { Ekstraksi dengan } \\
\mathrm{NaCl} 0,5 \mathrm{M}\end{array}$ & $\begin{array}{l}\text { Limbah sintetik kaolin } \\
\text { (250-300 NTU) }\end{array}$ & $8 \mathrm{~mL} / \mathrm{L}$ & - & $45-50$ & (Gunaratna dkk., 2007) \\
\hline Vigna unguilata & $\begin{array}{l}\text { Ekstraksi dengan } \\
\text { air }\end{array}$ & $\begin{array}{l}\text { Limbah sintetik kaolin } \\
\text { (200 NTU) }\end{array}$ & $21 \mathrm{mg} / \mathrm{L}$ & 5,4 & 97,5 & $\begin{array}{l}\text { (Hussain dan Haydar, } \\
\text { 2019) }\end{array}$ \\
\hline
\end{tabular}


Beberapa pengembangan aplikasi yang menarik adalah pengembangan koagulan magnetik dari koagulan alami serta kombinasi berbagai teknologi pengolahan air dan limbah cair. Pemanfaatan ekstrak kasar Moringa oleifera pertama kali dilakukan oleh Okoli dkk. (2012), yaitu protein sebagai bahan aktif koagulan diikat di permukaan besi nanopartikel (campuran $\gamma$ $\mathrm{Fe}_{2} \mathrm{O}_{3}$ dan $\mathrm{Fe}_{3} \mathrm{O}_{4}$ ). Penggunaan besi nanopartikelkelor menghilangkan $90 \%$ kekeruhan dalam kehadiran medan magnet dengan waktu pengendapan selama 12 menit. Waktu ini lebih cepat jika dibandingkan dengan pengendapan secara gravitasi biasa (240 menit) (Okoli dkk., 2012). Lebih lanjut grup Santos memanfaatkan besi nanopartikel $\mathrm{Fe}_{3} \mathrm{O}_{4}, \alpha$ atau pun $\gamma-\mathrm{Fe}_{2} \mathrm{O}_{3}$ dan ekstrak Moringa oleifera untuk mengolah air keruh dan limbah tekstil. Performa yang diperoleh sama baiknya dengan koagulan alami saja, akan tetapi membutuhkan waktu pengendapan yang jauh lebih singkat (Mateus dkk., 2018; Santos dkk., 2016; Santos dkk., 2018a; Santos dkk., 2018b). Pengembangan aplikasi ini memiliki beberapa keuntungan seperti waktu pengendapan yang singkat sehingga berpotensi memperkecil ukuran tangki sedimentasi. Selain itu besi nanopartikel dapat dipisahkan dari sludge yang terbentuk untuk digunakan kembali.

Kombinasi pemanfaatan koagulan alami dengan teknologi pengolahan lain telah dilakukan oleh berbagai peneliti. Ekstrak Moringa oleifera dikombinasi dengan teknik elektrokimia untuk mengolah limbah cair industri cat (Barbosa dkk., 2018). Dalam penelitian tersebut diperoleh penurunan kandungan organik sebesar $85 \%$, toksisitas air buangan yang lebih rendah, serta penghambatan pertumbuhan bakteri koliform pada air yang diolah. Proses koagulasi dengan ekstrak Moringa oleifera kemudian dilanjutkan mikro atau nanofiltrasi digunakan untuk mengolah limbah industri susu (Mateus dkk., 2017). Hasil menunjukkan terjadi penurunan COD sebesar 96\%, penurunan kekeruhan dan warna sebesar $99 \%$ dengan peningkatan performa membran seperti penurunan laju fouling membrane sebesar 63\%, peningkatan laju dan kualitas permeate. Kombinasi ekstrak Moringa oleifera dan adsorpsi menggunakan karbon aktif digunakan untuk mengolah air tanah. Dari kombinasi ini diperoleh penurunan kandungan ion nitrat dan kekeruhan sampai memenuhi baku mutu air minum (Rezende dkk., 2016).

Di sisi lain, aplikasi koagulan alami dengan bahan aktif ekstrak protein sebagian besar masih pada skala laboratorium, dan beberapa peneliti mengaplikasikannya pada skala pilot (BeltránHeredia dan Sánchez-Martín, 2009; Muyibi dan Alfugara, 2003). Beberapa hal yang menjadi tantangan dalam proses komersialisasi dari koagulan alami di antaranya adalah karakteristik limbah nyata yang bervariasi, ketersediaan tumbuhan sumber koagulan, biaya untuk memproses koagulan, selain keengganan industri untuk mengganti koagulan yang sudah biasa digunakan (Choy dkk., 2015; Folkard dan Sutherland, 2002; Freitas dkk., 2018). Untuk tujuan komersialisasi, maka teknologi pemrosesan protein dari kacang-kacangan tidak cukup sampai pada perolehan ekstrak kasar, tetapi perlu dilanjutkan sampai pada tahap pemurnian untuk memperoleh isolat protein. Berbagai teknologi yang dapat digunakan antara lain: penukar ion (Ghebremichael dkk., 2006; Ghebremichael, 2007), dialisis (Dezfooli dkk., 2016), membran ultrafiltrasi (Antov dkk., 2012; Prodanović dkk., 2013), spray drying (pengeringan kabut) (Mohammad dkk., 2013) dan lyophilization (pengeringan beku) (Mohamed dkk., 2015). Teknologi proses yang mudah, dapat di-scale up, dan murah menjadi penting dalam rangka komersialisasi ini.

Sekalipun demikian, ekstrak kasar protein dapat langsung dimanfaatkan jika teknologi ini diterapkan sebagai teknologi tepat guna untuk menyediakan air bersih di masyarakat. Berbagai penelitian telah menerapkan penggunaan koagulan alami dalam penyediaan air bersih pada skala pilot (Muyibi dan Alfugara, 2003; Pengchai dkk., 2012; Yongabi dkk., 2011b; Yongabi dkk., 2011a; Yongabi dan Knoll, 2015). Potensi lain adalah pembuatan produk berupa kemasan penjernih air yang di dalamnya terdapat kacangkacangan sebagai bahan aktif koagulan untuk 
skala kecil (rumah tangga) (Pooi dan Ng, 2018; Pritchard dkk., 2010;). Protein yang diendapkan dari ekstrak Moringa oleifera dapat disimpan sampai 78 minggu dalam bentuk padat pada suhu ruang (Garcia-Fayos dkk., 2016).

Kunci penerapan ekstrak kacang-kacangan sebagai koagulan alami pada ketersediaan kacang-kacangan lokal yang mudah didapat dan relatif murah (Choy dkk., 2014; Jadhav dan Mahajan, 2014; Oladoja, 2015). Pemanfaatan Moringa oleifera sebagai koagulan membutuhkan biaya hanya $15 \%$ dibandingkan alum dan soda abu per $1000 \mathrm{~m}^{3}$ air yang diolah (Sutherland dkk., 1994). Pada studi yang dilakukan oleh Hussain dan Haydar (2019), penggunaan ekstrak kasar kacang ercis (Vigna unguiculata) memberikan performa yang sama baiknya dengan alum, tetapi dengan biaya pengolahan separuh dibandingkan alum. Dilaporkan biaya pengolahan air dengan alum sebesar $\$ 41,6$ dan ekstrak kacang ercis $\$ 23,3$ per $1000 \mathrm{~m}^{3}$ air yang diolah (Haydar dkk., 2010; Hussain dan Haydar, 2019). Kajian ekonomi yang lebih mendalam serta dampak lingkungan terkait penggunaan koagulan alami masih dapat dieksplorasi. Selain itu, sumber protein yang paling banyak diteliti adalah Moringa oleifera, sehingga data dari jenis kacang-kacangan lain masih relatif terbatas. Dapat dilakukan studi lebih lanjut pula untuk eksplorasi sampai isolasi protein dari kacang-kacangan lain.

\section{Kesimpulan}

Pada tinjauan ini telah dibahas potensi protein kacang-kacangan, proses ekstraksi, serta pemanfaatannya sebagai koagulan alami. Ekstraksi protein menggunakan larutan garam $(0,5-1 \quad M)$ dengan dispersi merupakan proses yang umum digunakan. Cara ini memberikan hasil yang cukup efektif terhadap penurunan beberapa parameter air, seperti kekeruhan dan zat warna. Namun masih terdapat kendala pada peningkatan kandungan organik terlarut pada air yang telah diolah. Hal ini terjadi karena komponen organik lain yang ikut terekstrak. Sebagai teknologi tepat guna untuk penyediaan air bersih di masyarakat, pengolahan kacang-kacangan untuk koagulan alami cukup sampai tahap ekstraksi. Selain itu jenis kacang-kacangan yang digunakan dapat menyesuaikan dengan ketersediaan kacang-kacangan lokal. Untuk tujuan komersialisasi, perlu pemurnian lebih lanjut sehingga diperoleh isolat dengan menggunakan berbagai metode seperti pengendapan, penukar ion, dialisis, ultrafiltrasi, pengeringan kabut dan beku. Diperlukan berbagai penelitian lanjutan untuk memanfaatkan ekstrak protein dari kacang-kacangan sehingga dapat digunakan sebagai proses pengolahan air dan limbah cair yang lebih ramah lingkungan.

\section{Ucapan Terima Kasih}

Karya ilmiah ini merupakan bagian dari penelitian yang dibiayai oleh Lembaga Penelitian dan Pengabdian Masyarakat (LPPM) Universitas Katolik Parahyangan Skema Hibah Dosen Muda dengan kontrak No III/LPPM/2019-01/15-P. Penulis mengucapkan terima kasih atas bantuan pembiayaan yang diberikan.

\section{Daftar Pustaka}

Abidin, Z. Z., Ismail, N., Yunus, R., Ahamad, I. S. and Idris, A., 2011, A preliminary study on Jatropha curcas as coagulant in wastewater treatment, Environ.Technol., 32(9), 971-977

Abidin, Z. Z., Madehi, N. and Yunus, R., 2017, Coagulative behaviour of Jatropha curcas and its performance in wastewater treatment, Environ. Prog. Sustainable Energy, 36(6), 1709-1718

Abidin, Z. Z., Shamsudin, N. S. M., Madehi, N. and Sobri, S., 2013, Optimisation of a method to extract the active coagulant agent from Jatropha curcas seeds for use in turbidity removal, Ind. Crops Prod., 41, 319- 323

Alghamdi, S. S., 2009, Chemical composition of faba bean (Vicia faba 1.) genotypes under various water regimes, Pak. J. Nutr., 8(4), 477-482 
Antov, M. G., Šciban, M. B. and Petrovic, N. J., 2010, Proteins from common bean (Phaseolus vulgaris) seed as a natural coagulant for potential application in water turbidity removal, Bioresour.Technol. , 101, 21672172

Antov, M. G., Sciban, M. B. and Prodanovic, J. M., 2012, Evaluation of the efficiency of natural coagulant obtained by ultrafiltration of common bean seed extract in water turbidity removal, Ecological Engineering, 49, 48- 52

Asif, M. B., Majeed, N., Iftekhar, S., Habib, R., Fida, S. and Tabraiz, S., 2016, Chemically enhanced primary treatment of textile effluent using alum sludge and chitosan, Desalin. Water Treat., 57, 7280-7286

Audain, E., Ramos, Y., Hermjakob, H., Flower, D. R. and Perez-Riverol, Y., 2016, Accurate estimation of isoelectric point of protein and peptide based on amino acid sequences, Bioinformatics, 32(6), 821-828

Baptista, A. T. A., Silva, M. O., Gomes, R. G., Bergamasco, R., Vieira, M. F. and Vieira, A. M. S., 2017, Protein fractionation of seeds of Moringa oleifera lam and its application in superficial water treatment, Sep. Purif. Technol., 180, 114-124

Barbosa, A. D., Silva, L. F. d., Paula, H. M. d., Romualdo, L. L., Sadoyama, G. and Andrade, L. S., 2018, Combined use of coagulation ( $M$. oleifera) and electrochemical techniques in the treatment of industrial paint wastewater for reuse and/or disposal, Wat. Res., 145, 153-161

Beltrán-Heredia, J. and Sánchez-Martín, J., 2009, Improvement of water treatment pilot plant with Moringa oleifera extract as flocculant agent Environ. Technol., 30(6), 525-534

Beltrán-Heredia， J., Sánchez-Martín， J. and Gómez-Munoz, M. C., 2010, New coagulant agents from tannin extracts: Preliminary optimisation studies, Chem. Eng. J., 162, 1019-1025

Birima, A. H., Ahmed, A. T., Noor, M. J. M. M., Sidek, L. M., Muda, Z. C. and Wong, L. S., 2015, Application of salt extracted peanut seeds in the pretreatment of palm oil mill effluent (POME), Desalin. Water Treat., 55(2196-2200),

Birima, A. H., Hammad, H. A., Desa, M. N. M. and Muda, Z. C., 2013, Extraction of natural coagulant from peanut seeds for treatment of turbid water IOP Conf. Series: Earth and Environmental Science, 16, 1-4

Bolto, B. and Gregory, J., 2007, Organic polyelectrolytes in water treatment, Wat. Res., 41, 2301-2324

Campbell, K. A., Glatz, C. E., Johnson, L. A., Jung, S., Moura, J. M. N. d., Kapchie, V. and Murphy, P., 2011, Advances in aqueous extraction processing of soybeans, J. Am. Oil. Chem. Soc., 88, 449-465

Chen, W. and Berg, J. C., 1993, The effect of polyelectrolyte dosage on floc formation in protein precipitation by polyelectrolytes, Chem. Eng. Sci., 48(10), 1775-1784

Chethana, M., Sorokhaibam, L. G., Bhandari, V. M., Raja, S. and Ranade, V. V., 2016, Green approach to dye wastewater treatment using biocoagulants, ACS Sustainable Chem. Eng., 4(5), 2495-2507

Choi, B. D., Wong, N. A. K. and Auh, J.-H., 2017, Defatting and sonication enhances protein extraction from edible insects, Korean J. Food Sci. Anim. Resour., 37(6), 955-961

Choy, S. Y., Prasad, K. M. N., Wu, T. Y., Raghunandan, M. E. and Ramanan, R. N., 2014, Utilization of plant-based natural coagulants as future alternatives towards sustainable water clarification, J. Environ. Sci., 26(11), 2178-2189

Choy, S. Y., Prasad, K. M. N., Wu, T. Y. and Ramanan, R. N., 2015, A review on common vegetables and legumes as promising plantbased natural coagulants in water clarification, Int. J. Environ. Sci. Technol., 12, 367-390

Choy, S. Y., Prasad, K. N., Wu, T. Y., Raghunandan, M. E. and Ramanan, R. N., 2016, Performance of conventional starches as natural coagulants forturbidity removal, Ecological Engineering, 94, 352-364

Ciabotti, S., Silva, A. C. B. B., Juhasz, A. C. P., Mendonça, C. D., Tavano, O. L., Mandarino, J. M. G. and Gonçalves, C. A. A., 2016, Chemical composition, protein profile, and 
isoflavones content in soybean genotypes with different seed coat colors, Int. Food Res. J., 23(2), 621-629

Collins, K. D., 2004, Ions from the Hofmeister series and osmolytes: Effects on proteins in solution and in the crystallization process, Methods, 34, 300-311

Dalvand, A., Gholibegloo, E., Ganjali, M. R., Golchinpoor, N., Khazaei, M., Kamani, H., Hosseini, S. S. and Mahvi, A. H., 2016, Comparison of moringa stenopetala seed extract as a clean coagulant with alum and moringa stenopetala-alum hybrid coagulant to remove direct dye from textile wastewater Environ. Sci. Pollut. Res., 23(16), 1639616405

Dezfooli, S. M., Uversky, V. N., Saleem, M., Baharudin, F. S., Hitam, S. M. S. and T.Bachmann, R., 2016, A simplified method for the purification of an intrinsically disordered coagulant protein from defatted Moringa oleifera seeds, Process Biochem., 51(8), 1085-1091

Fernandez-Quintela, A., Macarulla, M. T., Barrio, A. S. D. and Martinez, J. A., 1997, Composition and functional properties of protein isolates obtained from commercial legumes grown in Northern Spain, Plant Foods Hum. Nutr., 51, 331-342

Folkard, G. and Sutherland, J., 2002, Development of a naturally derived coagulant for water and wastewater treatment, Water Sci Tech-W Sup, 2(5-6), 89-94

Freitas, T. K. F. S., Almeida, C. A., Manholer, D. D., Geraldino, H. C. L., Souza, M. T. F. d. and Garcia, J. C., 2018. Review of utilization plant-based coagulants as alternatives to textile wastewater treatment. in: S. S. Muthu(Eds.),Detox fashion, textile science and clothing technology, Springer Nature Singapore Pte Ltd., pp 27-79.

Garcia-Fayos, B., Arnal, J. M., Sancho, M. and Rodrigo, I., 2016, Moringa oleifera for drinking water treatment: Influence of the solvent and method used in oil extraction on the coagulant efficiency of the seed extract, Desalin. Water Treat., 57(48-49), $23397-$ 23404
Ghebremichael, K., 2007, Overcoming the drawbacks of natural coagulants for drinking water treatment, Water Sci. Tech-W Sup., 7(4), 87-93

Ghebremichael, K. A., Gunaratna, K. R. and Dalhammar, G., 2006, Single-step ion exchange purification of the coagulant protein from Moringa oleifera seed, Appl. Microbiol. Biotechnol., 70, 526-532

Gregory, J., 2006. Particles in water: Properties and processes, Taylor and Francis, London

Gunaratna, K. R., Garcia, B., Andersson, S. and Dalhammar, G., 2007, Screening and evaluation of natural coagulants for water treatment, Water Sci. Technol.: Water Supply, 7(5-6), 19-25

Guo, M. Q., Hu, X., Wang, C. and Ai, L., 2017. Polysaccharides: Structure and solubility. in: Z. Xu(Eds.), Solubility of polysaccharides. IntechOpen.

Haydar, S., Ahmad, H. and Aziz, J. A., 2010, Optimization of coagulation flocculation in the treatment of canal water, Environ. Eng. Manage. J., 9, 1563-1570

Hu, H., Fan, T., Zhao, X., Zhang, X., Sun, Y. and Liu, H., 2017, Influence of $\mathrm{pH}$ and salt concentration on functional properties of walnut protein from different extraction methods, J. Food. Sci. Technol., 54(9), 2833-2841

Hussain, G. and Haydar, S., 2019, Exploring potential of pearl millet (Pennisetum glaucum) and black-eyed pea (Vigna unguiculata subsp. unguiculata) as biocoagulants for water treatment, Desalin. Water Treat., 143, 184-191

Hyde, A. M., Zultanski, S. L., Waldman, J. H., Zhong, Y.-L., Shevlin, M. and Peng, F., 2017, General principles and strategies for saltingout informed by the Hofmeister series, Org. Process Res. Dev., 21(9), 1355-1370

Jadhav, M. V. and Mahajan, Y. S., 2014, Assessment of feasibility of natural coagulants in turbidity removal and modeling of coagulation process, Desalin. Water Treat., 52 (31-33), 5812-5821

Jeon, J.-R., Kim, E.-J., Kim, Y.-M., Murugesan, K., Kim, J.-H. and Chang, Y.-S., 2009, Use of 
grape seed and its natural polyphenol extracts as a natural organic coagulant for removal of cationic dyes, Chemosphere, 77, 1090-1098

Kristianto, H., Paulina, S. and Soetedjo, J. N. M., 2018, Exploration of various Indonesian indigenous plants as natural coagulant for synthetic turbid water, IJTech, 9(3), 464-471

Kristianto, H., Rahman, H., Prasetyo, S. and Sugih, A. K., 2019, Removal of congo red aqueous solution using Leucaena leucocephala seed's extract as natural coagulant, Appl. Water Sci., 9(4), Article No 88

Kukic, D. V., Sciban, M. B., Prodanovic, J. M., Tepic, A. N. and Vasic, M. A., 2015, Extracts of fava bean (Vicia faba l.) seeds as natural coagulants, Ecol. Eng., 84, 229-232

Kumar, R., Sharma, K., Tiwary, K. P. and Sen, G., 2013, Polymethacrylic acid grafted psyllium (psy-g-pma): A novel material for waste water treatment, Appl. Water Sci., 3(1), 285-291

Lee, C. S., Robinson, J. and Chong, M. F., 2014, A review on application of flocculants in wastewater treatment, Process Safety and Environmental Protection, 92(6), 489-508

Mainieri, D., Morandini, F., Maîtrejean, M., Saccani, A., Pedrazziniand, E. and Vitale, A., 2014, Protein body formation in the endoplasmic reticulum as an evolution of storage protein sorting to vacuoles: Insights from maize $\gamma$-zein, Front. Plant Sci., 5, Article No. 331

Makeri, M. U., Mohamed, S. A., Karim, R., Ramakrishnan, Y. and Muhammad, K., 2017, Fractionation, physicochemical, and structural characterization of winged bean seed protein fractions with reference to soybean, Inter. J. Food Prop., 20(S2), S2220-S2236

Mateus, G. A. P., Formentini-Schmitt, D. M., Nishi, L., Fagundes-Klen, M. R., Gomes, R. G. and Bergamasco, R., 2017, Coagulation/flocculation with Moringa oleifera and membrane filtration for dairy wastewater treatment, Water Air Soil Pollut., 228(9), 1-13

Mateus, G. A. P., Paludo, M. P., Santos, T. R. T. d., Silva, M. F., Nishi, L., Fagundes-Klen, M.
R., Gomes, R. G. and Bergamasco, R., 2018, Obtaining drinking water using a magnetic coagulant composed of magnetite nanoparticles functionalized with Moringa oleifera seed extract, J. Environ. Chem. Eng., 6 (4), 4084-4092

Mbogo, S. A., 2008, A novel technology to improve drinking water quality using natural treatment methods in rural tanzania, Environ. Health, 70(7), 46-50

Meng, G. and Ma, C.-Y., 2002, Characterization of globulin from Phaseolus angularis (red bean), Int. J. Food Sci. Technol., 37, 687695

Mishra, A., Yadav, A., Agarwal, M. and Rajani, S., 2004, Polyacrylonitrile-grafted Plantago psyllium mucilage for the removal of suspended and dissolved solids from tannery effluent, Colloid and Polymer Science, 282(3), 300-303

Mohamed, E. H., Mohammad, T. A., Noor, M. J. M. M. and Ghazali, A. H., 2015, Influence of extraction and freeze-drying durations on the effectiveness of Moringa oleifera seeds powder as a natural coagulant, Desalin. Water Treat., 55(13), 3628-3634

Mohammad, T. A., Mohamed, E. H., Noor, M. J. M. M. and Ghazali, A. H., 2013, Coagulation activity of spray dried salt extracted Moringa oleifera, Desalin. Water Treat., 51(7-9), 1941-1946

Müntz, K., 1998. Globulins from legume seeds: Structure and function during storage and reactivation. in: J. Guéguen and Y. Popineau(Eds.), Plant proteins from European crops. Springer, Berlin, Heidelberg, pp 3-12.

Musa, M., Hamid, K. H. K., Abidin, H. Z. and Rodhi, M. N. M., 2015. Coagulant from chemically modified fish scale for textile wastewater treatment in: $M$. Hashim(Eds.),ICGSCE 2014, Springer, Singapore, pp 69-77.

Muthuraman, G. and Sasikala, S., 2014, Removal of turbidity from drinking water using natural coagulants, J. Ind. Eng. Chem., 20, 17271731

Muyibi, S. and Alfugara, A., 2003, Treatment of surface water with Moringa oleifera seed 
extract and alum - a comparative study using a pilot scale water treatment plant, Int. J. Environ. Stud., 60(6), 617-626

Muyibi, S. A., Noor, M. J. M. M., Leong, T. K. and Loon, L. H., 2002, Effects of oil extraction from Moringa oleifera seeds on coagulation of turbid water, International Journal of Environmental Studies, 59(2), 243-254

Natarajan, S. S., Pastor-Corrales, M. A., Khan, F. H. and Garrett, W. M., 2013, Proteomic analysis of common bean (Phaseolus vulgaris l.) by two-dimensional gel electrophoresis and mass spectrometry, J. Basic Appl. Sci., 9, 424-437

Ndabigengesere, A., Narasiah, K. S. and Talbot, B. G., 1995, Active agents and mechanism of coagulation of turbid waters using Moringa oleifera, Wat. Res., 29(2), 703-710

Nehete, J. Y., Bhambar, R. S., Narkhede, M. R. and Gawali, S. R., 2013, Natural proteins: Sources, isolation, characterization and applications, Pharmacogn Rev., 7(14), 107116

Okoli, C., Boutonnet, M., Jaras, S. and RajaraoKuttuva, G., 2012, Protein-functionalized magnetic iron oxide nanoparticles: Time efficient potential-water treatment, J. Nanopart. Res., 14, 1194

Okuda, T., Baes, A. U., Nishijima, W. and Okada, M., 1999, Improvement of extraction method of coagulation active components from Moringa oleifera seed, Wat. Res. , 33(15), 3373-3378

Oladoja, N. A., 2015, Headway on natural polymeric coagulants in water and wastewater treatment operations, Journal of Water Process Engineering, 6, 174-192

Oladoja, N. A., Unuabonah, E. I., Amuda, O. S. and Kolawole, O. M., 2017. Polysaccharides as a green and sustainable resources for water and wastewater treatment, Springer.

Ozacar, M. and Sengil, I. A., 2002, The use of tannins from Turkish acorns (valonia) in water treatment as a coagulant and coagulant aid, Turkish K. Eng. Env. Sci, 26，255-263

Pengchai, P., Keawkhun, K. and Suwapet, N., 2012, Low-cost engineering techniques in sustainable operation of a rural clean water plant in Thailand, Sci. Tech. and Dev., 31(3), 271-279

Pooi, C. K. and Ng, H. Y., 2018, Review of lowcost point-of-use water treatment systems for developing communities, npj Clean Water, 1, Article No 11

Pritchard, M., Craven, T., Mkandawire, T., Edmondson, A. S. and O'Neill, J. G., 2010, A comparison between Moringa oleifera and chemical coagulants in the purification of drinking water - an alternative sustainable solution for developing countries, Physics and Chemistry of the Earth, 35, 798-805

Prodanović, J. M., Antov, M. G., Šćiban, M. B., Ikonić, B. B., Kukić, D. V., Vasić, V. M. and Ivetić, D. Ž., 2013, The fractionation of natural coagulant extracted from common bean by use of ultrafiltration membranes, Desalin. Water Treat., 51(1-3), 442-447

Ramavandi, B., 2014, Treatment of water turbidity and bacteria by using a coagulant extracted from Plantago ovata, Water Res. Ind., 6, 36-50

Rath, S. K. and Singh, R. P., 1997, Flocculation characteristics of grafted and ungrafted starch, amylose, and amylopectin, J. Appl. Polym. Sci. , 66, 1721-1729

Rezende, D., Nishi, L., Coldebella, P. F., Silva, M. F., Vieira, M. F., Vieira, A. M. S., Bergamasco, R. and Fagundes-Klen, M. R., 2016, Groundwater nitrate contamination: Assessment and treatment using Moringa oleifera lam. seed extract and activated carbon filtration, Can. J. Chem. Eng., 94(4), 725732

Santos, T. R. T., Silva, M. F., Nishi, L., Vieira, A. M. S., Klein, M. R. F., Andrade, M. B., Vieira, M. F. and Bergamasco, R., 2016, Development of a magnetic coagulant based on moringa oleifera seed extract for water treatment, Environ. Sci. Pollut. Res., 23(8), 7692-7700

Santos, T. R. T. d., Mateus, G. A. P., Silva, M. F., Miyashiro, C. S., Nishi, L., Andrade, M. B. d., Fagundes-Klen, M. R., Gomes, R. G. and Bergamasco, R., 2018a, Evaluation of magnetic coagulant $\left(\alpha-\mathrm{Fe}_{2} \mathrm{O}_{3}-\mathrm{MO}\right)$ and its 
reuse in textile wastewater treatment, Water Air Soil Pollut., 229, 92

Santos, T. R. T. d., Silva, M. F., Andrade, M. B. d., Vieira, M. F. and Bergamasco, R., 2018b, Magnetic coagulant based on Moringa oleifera seeds extract and super paramagnetic nanoparticles: Optimization of operational conditions and reuse evaluation, Desalin. Water Treat., 106, 226-237

Sathe, S. K., 2002, Dry bean protein functionality, Crit. Rev. Biotechnol., 22(2), 175-223

Sebei, K., Gnouma, A., Herchi, W., Sakouhi, F. and Boukhchina, S., 2013, Lipids, proteins, phenolic composition, antioxidant and antibacterial activities of seeds of peanuts (Arachis hypogaea l.) cultivated in Tunisia, Biol. Res., 46(3), 257-263

Sethi, P. and Kulkarni, P. R., 1993, Fractionation of Leucaena seed-kernel proteins based on their solubility characteristics, Food Chem., 48, 173-177

Sethi, P. and Kulkarni, P. R., 1994, Chemical composition of Leucaena leucocephala seeds, Inter. J. Food Sci. Nutr., 45, 5-13

Shehata, A. A. Y. and Thannoun, A. M., 1981, Preparation of protein isolates from Iraqi mung beans with their chemical, nutritional and solubility characteristics, J. Plant Foods, 3(4), 265-273

Shewry, P. R., Napier, J. A. and Tatham, A. S., 1995, Seed storage proteins: Structures and biosynthesis, The Plant Cell, 7, 945-956

Shimelis, E. A. and Rakshit, S. K., 2005, Proximate composition and physico-chemical properties of improved dry bean (Phaseolus vulgaris l.) varieties grown in Ethiopia, LWT - Food Sci. Technol., 38(4), 331-338

Siddique, A. B. and Wright, D., 2003, Effects of different drying time and temperature on moisture percentage and seed quality (viability and vigour) of pea seeds (Pisum sativum l.), Asian J. Plant Sci., 2(13), 978982

Singh, R., Kumar, S. and Garg, M., 2016. Domestic wastewater treatment using tanfloc: A tannin based coagulant in: N. J. Raju(Eds.),Geostatistical and geospatial approaches for the characterization of natural resources in the environment, Springer.

Srinivasan, P. T., Viraraghavan, T. and Subramanian, K. S., 1999, Aluminium in drinking water: An overview, Water SA, 25(1), 47-56

Sutherland, J. P., Folkard, G. K., Mtawali, M. A. and Grant, W. D., 1994, Moringa oleifera as a natural coagulant, 20th WEDC Conference, Colombo, Sri Lanka.

Swamylingappa, B. and Srinivas, H., 1994, Preparation and properties of protein isolate from hexane-acetic acid treated commercial soybean meal, J. Agric. Food Chem., 42(12), 2907-2911

Teh, C. Y., Wu, T. Y. and Juan, J. C., 2014, Optimization of agro-industrial wastewater treatment using unmodified rice starch as a natural coagulant, Industrial Crops and Products, 56, 17-26

Theodoro, J. D. P., Lenz, G. F., Zara, R. F. and Bergamasco, R., 2013, Coagulants and natural polymers: Perspectives for the treatment of water, Plastic and Polymer Technology, 2(3), 55-62

Verma, A. K., Dash, R. R. and Bhunia, P., 2012, A review on chemical coagulation/flocculation technologies for removal of colour from textile wastewaters, J. Environ. Manage., 93, 154-168

Vijayaraghavan, G. and Shanthakumar, S., 2016, Performance study on algal alginate as natural coagulant for the removal of Congo red dye, Desalin. Water Treat., 57, 6384-6392

Vilkhu, K., Mawson, R., Simons, L. and DarrenBates, 2008, Applications and opportunities for ultrasound assisted extraction in the food industry - a review, Innovative Food Sci. Emerging Technol., 9(2), 161-169

Yin, C.-Y., 2010, Emerging usage of plant-based coagulants for water and wastewater treatment, Process Biochem., 45, 1437-1444

Yongabi, K. A. and Knoll, L., 2015, A biocoagulant slow sand filtration for disinfection of toxoplasma Gondii oocysts Mezam river in bamenda, cameroon, African Journal of Biotechnology, 14(11), 937-943 
Yongabi, K. A., Lewis, D. M. and Harris, P. L., 2011a, Indigenous plant based coagulants/disinfectants and sand filter media for surface water treatment in Bamenda, Cameroon, African Journal of Biotechnology, 10(43), 8625-8629

Yongabi, K. A., Lewis, D. M. and Harris, P. L., 2011b, Integrated phyto-disinfectant-sand filter drum for household water treatment in sub-saharan Africa, J. Environ. Sci. Eng., 5, 947-954

Zhang, J., 2012. Protein-protein interactions in salt solutions. in: W. Cai and $H$. Hong(Eds.),Protein-protein interactions computational and experimental tools. InTechOpen, China, pp 359-376. 